\title{
The Challenges of Teaching History in a Democracy: the Case of Latvia
}

\author{
Aija Abens
}

\begin{abstract}
The occupation of Latvia by the Soviet Union after World War II resulted in the creation of curriculum and methodology that required embracing of a Russo-centric, totalitarian communist system that was formalist in nature and denigrated previously accepted national values and ideals. In 1991, after Latvia regained its independence, democratic education once again came to the forefront, grounded theoretically in the significance and development of democratic and civic and national educational ideals. However, embracing democratic teaching principles that encourage critical thinking and alternative theoretical approaches has been difficult for a cohort of educators and administrators trained to be transmitters of information, rather than facilitators of participatory educational practices. The practice of history teaching, as a transmitter of social integration and builder of a civic-minded society, also came under scrutiny. My theoretical basis reflects the interconnectedness of sociology, politics, and pedagogy that acknowledge the ties between history teaching, democratic education and identity, their effects on individual and societal development of historic understanding, and the resulting development and assessment of society by the individual, society, and the state. Sources include not only literature and primary sources, but also survey results and reflections. Results show that current history education practice includes democratic principles; however, the rigid nature of indoctrination characteristic of totalitarian regimes has had a lasting effect on methodology, resulting in continuation of many of the formalist practices and values internalised during Soviet occupation.
\end{abstract}

Keywords: democratic teaching, post-Soviet Latvia, history teaching

\section{Introduction}

Key elements for education for democracy include promotion of moral values generally accepted by a democratic society, acknowledgment of role models exhibiting good character within the school and general community, guided peer discussion of moral issues and participation in school and classroom governance, learning about character through curriculum, inclusion of the family, particularly parents in moral education, and finally, practical experience in democratic behavior. Nevertheless, there is some disagreement about what encompasses the basis of democratic education, particularly in the realm of instilling desirable, i.e. moral habits - for some it is reduced to a form of attitude change, but for others it means a more liberal cognitive orientation. ${ }^{1}$

1 M. W. Berkowitz, 'Civics and Moral Education', in B. Moon, M. Ben-Peretz (eds.), Routledge International Companion to Education, London, Routledge, 2000, p. 897. 
This paper will address the main issues associated with the effects on the teaching of history, resulting from a drastic paradigm shift - the change from a Soviet centralised authoritarian education system to an independent Latvian liberal democratic one. Has a shift in attitude occurred as a result, or is a more liberal cognitive orientation necessary to affect true change? What are the main hurdles in the way of achieving democratic history teaching practices in Latvia?

The theoretical basis of my research is based on the significance of history teaching in the development of democratic and civic educational ideals and modern critical theorists' work on power, language, memory, and other related issues, as well as how critical pedagogy in history teaching relates to the individual, society, and the nation. This paper addresses some of the difficulties associated with teaching history after a radical paradigm shift.

Under totalitarian regimes, there is no leeway for free and open examination and discussion of alternative forms of evidence that may contradict state ideology. ${ }^{2}$ Wild notes that the young and their physical weakness and mental confusion are manipulated through fear and force, and in higher levels of education, authoritarianism encourages imitation and discourages questions and discussion. This method often succeeds in the intact transmission from one generation to the next of a rigid social order, wiping out spontaneity and originality and offering little chance of correcting previous mistakes. ${ }^{3}$ Fromm notes that aspects of authoritarian ethics are apparent in the unreflective value judgments made by the average adult. ${ }^{4}$ Ironically, this must inevitably lead to inherent distrust and skepticism of any concepts or thought not sanctioned by the ruling order, even though the sanctioned is itself looked upon as lies.

Modern pluralistic democracies tend to be aware of using various teaching methods, including a variety of sources, but can still come under political ideological pressure. Pluralistic democracies suppose to educate for democracy, which includes participation in the democratic process, and also involves general moral education ${ }^{5}$ as part of an un-admitted socio-centric tendency to see things through a middle-class lens. ${ }^{6}$ Dewey argues that experience lies at the core of education and that educating for democracy requires participation in the democratic process. ${ }^{7}$ Friere takes this further by stressing the revolutionary

2 T. Taylor, 'The Past, Present and Future of History Teaching in Schools', in B. Moon, M. Ben-Peretz (eds.), Routledge International Companion to Education, London, Routledge, 2000, pp. $850-852$.

3 J. Wild, 'Education and Human Society: A Realistic View,' in N. B. Henry (ed.), Modern Philosophies and Education, Chicago, University of Chicago Press, 1955, pp. 17-56. Available: http://www.questia. com/PM.qst?a=o\&d=11822419 (accessed 6 May 2007).

4 E. Fromm, Man for Himself: an Inquiry into the Psychology of Ethics, London, Routledge, 1947/1999, pp. 9-10.

${ }_{5}$ M. W. Berkowitz, 'Civics and Moral Education', in B. Moon, M. Ben-Peretz (eds.), Routledge International Companion to Education, London, Routledge, 2000, pp. 897-908.

6 R. Preiswerk, D. Perrot, Ethnocentrism and History: Africa, Asia and Indian America in Western Textbooks, New York, NOK Publishers International, 1978, p. 27.

7 J. Dewey, Democracy and Education, New York, McMillan, 1916. 
nature of truly democratic education and the need for awareness of civic and political responsibilities and the acquisition of an analytical attitude towards authority. ${ }^{8}$

My sources include articles from the pedagogical press, government websites, conference proceedings, and published methodological materials as well as published survey results and interviews.

\section{Teaching under renewed independence}

Liberalism and decentralisation (1991-1995). With the collapse of the Soviet Union and the regaining of independence in 1991, Latvia was once again faced with the daunting task of drastically restructuring its education. The rejection of the anti-humanist nature of Marxist/Leninist doctrine of a centralised authoritarian Soviet system was clear, but its replacement was not. Educationalists were required to "retool" an educational system that was highly centralised, politicised in its Russo-centric communist rhetoric, and formalist in its didactic approach. In addition to changes in political rhetoric and teaching methods, the education system faced challenges with regard to creation of a curriculum that reflected democratic ideals of inclusivity, but was also a unifier of Latvian society.

In 1991, mirroring the situation in 1940 when Latvia was occupied by Soviets, the new government of Latvia was charged with the task of introducing education policies that would turn previous doctrine on its head. Many Soviet era textbooks, particularly history textbooks, were no longer acceptable, and dissemination of information took place using the press. Articles in pedagogical and general press discussed in great detail theories of democratic education, proposed policies, and the future of education in general. Many articles about historical events also appeared, offering a Latvian interpretation of previously silenced events or those that been presented through the lens of Soviet Communist historiography.

During the first heady years of renewed independence, Latvian educators and policy makers were plunged into a maelstrom of discussion on how to implement democratic education. The West and its values had been demonised under Soviet rule, resulting in idealisation of all things Western by many Soviet citizens. Thus, Western practices became a role model for the new educational system of Latvia. A realisation of the inferior nature of the system under which they had been operating led to the initial attitude that everything foreign (i.e. Western) must be better, which was apparent as the government pursued policies and created agencies mirroring Western practice. This often resulted in a very superficial and idealised view of democratic teaching: Practical applications and suggestions were few and usually based on discussions held with visiting Western-trained educators or observations made on short visits to foreign countries.

8 P. Freire, Pedagogy of the Oppressed, $3^{\text {rd }}$ ed., London, Bloomsbury Academic, 2000. 
Former history teacher and current head of the Latvian National Centre for Education Guntars Catlaks published a study in 2001 that reviewed the educational reforms of the first ten years of Latvia's renewed statehood. ${ }^{9} \mathrm{He}$ reflected that education is a tool for reform, one that indicates the kind of society one wishes to have and which should instill in people desired characteristics, knowledge, and behaviour models. However, he also noted that education reacts slowly to changes in society.

Catlaks described the changes in education during the first approximately ten years of independence as consisting of two phases. The first phase, from 1989 to 1995 , he characterised as a wave of liberalism and decentralisation and the belief that freedom itself would resolve various issues. A democratic model of education was already available - the only thing left to do was to implement it. However, he pointed out that the majority of educators in schools and institutes of higher education in the 1990s were products of the 1970s, revealing an underlying problem in the transference of skills required for democratic teaching to teachers who had no theoretical knowledge or practical experience teaching in such a manner. Not only were teachers not prepared methodologically for democratic teaching, but they also lacked a new curriculum for subjects that had been highly politicised under Soviet rule, most notably history.

With the introduction of glasnost and perestroika by Gorbachev in the late 1980s in the Soviet Union, Latvian educators finally had the opportunity to travel to democratic countries to witness democratic education in action. They were in awe of the various teaching and administration methods, school activities, and equipment available to teachers and students. The majority of the descriptions of these visits focused on resources available to teachers and administrators and, to a limited degree, the methods teachers used in their classrooms.

A director of a secondary school travelled to Finland for two weeks in 1990, and he reflected on his visit in the pedagogic newspaper Izglìtiba [Education]. ${ }^{10}$ He noted that democratic education included creation of parent councils and integration of schools into local communities, a trend that had already begun to appear in Latvia in the late 1980s. But his experience made him believe that students need more say in curriculum development and that curriculum should be geared to a changing society. He also highlighted the various teaching methods used by teachers and the use of technology in administration of Finnish schools. Teacher education was mentioned only in passing as an issue of preparedness for teaching in democratic schools, without any mention of actually changing the existing teacher education system in Latvia.

\footnotetext{
${ }^{9}$ G. Catlaks, 'Demokrātiskās pārmaiņas izglìīibā; valsts izglìīibas politikas pārskats 1991-2001' [Democratic changes in education; state educational policy review 1991-2001], Providus, 20 November 2001. Available: http://providus.lv/article/demokratiskas-parmainas-izglitibavalsts-izglitibas-politikas-parskats-1991-2001 (accessed 13 September 2016).

${ }^{10}$ E. Vilks, 'Kurš teiks gala vārdu?' [Who has the final word?], Izglìtība [Education], 3 January 1990, p. 6.
} 
The possible difficulties of "re-educating" those in charge was also alluded to in 1990 by Aldonis Builis, the then Latvian SSR Minister of Education, who accurately noted that the "hardest nut to crack" would be the thought processes of those who worked in the "state machinery." ${ }^{11}$ His statement is quite telling as an instrument of that same state machinery, it was his job to ensure that all members of the education system followed the strict policies handed down from above. Perhaps his administrative experience in a highly centralised system gave him insight into the inevitable bureaucratic difficulties caused by a radical paradigm shift. But, it was not just the thinking of the school system's bureaucrats that would be difficult to change, but also that of the teachers.

Discussions on professional development were often dominated by administrative practice. Teacher education models were the main topic at a discussion session led by the head of the University of Latvia Faculty of Pedagogy held in 1994; however, press coverage indicates that proceedings focused on administrative issues regarding which type of higher education institution would be responsible for teacher preparation, questions of financing models for newly forming institutes of higher education, an upper age limit for mandatory schooling, and other administrative issues. ${ }^{12}$ There was no mention of actual teacher preparation practice or models that could be attributed to democratic education, clearly indicating that bureaucratic restructuring of higher education institutions was paramount.

Yet, the importance of substantive teacher education was not totally absent. One of the rare articles to comment on teacher preparation stressed the role of the teacher as the centre of the democratic classroom in that s/he should allow children to express their opinions and that s/he should teach children to respect the opinions of others. ${ }^{13}$ The author noted that the rector of the newly formed Riga Teacher Training and Educational Management Academy stressed the need to train teacher candidates for teaching in a democratic classroom and not to focus on their teaching subject, because they should already be sufficiently knowledgeable in their chosen teaching field. This may have been clear for subjects such as math and science, but politicised subjects, such as history, needed to be addressed directly. How this would take place was not discussed.

Zeiberte's ${ }^{14}$ overview of the history of structural changes in organisation and management of teacher professional development since regaining

${ }^{11}$ A. Builis, 'Domu krustugunīs' [In the crossfire of opinions], Izglitīiba [Education], 7 February 1990, p. 4.

${ }^{12}$ D. Siliņa, 'Kā izglìtosim skolotājus?' [How shall we educate teachers?], Izglìtìba un Kultūra [Education and Culture], 24 February 1994, p. 6.

${ }^{13} \mathrm{~J}$. Stabiņš, 'Skolotājs - demokrātijas centrāe?' [The teacher - in the centre of democracy?], Izglìtība un Kultūra [Education and Culture], 30 May 1996, p. 8.

${ }^{14}$ L. Zeiberte, 'Reformu gaita Latvijas pedagogu tālākizglìitības sistēmā pēc 1991.gada' [The course of reform in the Latvian teacher higher education system after 1991], Daugavpils Universitātes 53. starptautiskās zinätniskās konferences materiāli [Proceedings of the $53^{\text {rd }}$ International Scientific Conference of Daugavpils University], Daugavpils, Daugavpils Universitātes Akadēmiskais apgāds Saule, 2011. Available: http://www.dukonference.lv/files/proceedings_of_ conf/53konf/pedagogija/Zeiberte.pdf (accessed 20 September 2017). 
independence indicated that the centralised top-down system was slowly turning to autonomy, resulting in a lack of systematic coordination of the continuing professional development of teachers. Most offerings were shortterm theoretical seminars, which did not include practical applications: these projects did not guarantee quality and were not a substitute for long-term management of further education. All teachers were expected to participate in forms of continuing education, as were school administrators, but Zeiberte noted that a lack of strategic planning, succession, coherence, and continuity plagued teacher professional development.

In 1995, Armands Kalniňs, the then secretary of the Ministry of Education and Science (MoES), wrote about education leadership and characterised the period 1989-1995 as one of "restructuring" as opposed to reforms, stressing the need for sharing theories and being able to pick and choose the elements that most suited the situation. ${ }^{15}$ His main criticisms of education reforms of this period centred on difficulties in systematizing the organisation of primary, secondary, and tertiary education, difficulties in the co-existence of new ideas with old traditions, lack of financing for administration and teaching resources, and finally, the lack of a conceptual vision. Most reforms dealt with decentralisation of the state education system, giving municipalities and townships control over local school administration. Decentralisation also focused on changes in curriculum, developing new student assessment and final exam criteria, creating and distributing new educational literature, and developing control systems to assess teaching efficacy, as well as the development of a private education system and associated accreditation criteria. This was particularly evident in tertiary education with the appearance of many private higher education institutions that competed with state schools, accompanied by the restructuring of education programmes and reclassifying of degrees issued during the Soviet era to adhere to a more European-looking education system. Yet, Kalniņš noted that there were those who were opposed to these changes, most frequently citing the supposed arbitrariness of the democratic system and the need for strong central control to ensure financing for the education system.

Regaining control (1995-1999). The second series of changes took place from 1995 to 1999 and are described by Catlaks ${ }^{16}$ as a reaction to this wave of liberalism and decentralisation - attempts were made to regain state control and create standards for the education system. Many initiatives had taken place, but they were haphazard and were not balanced and coordinated throughout the education system. Progress was evaluated primarily by how well initiatives, initiated from above, had been implemented and not how these changes

\footnotetext{
${ }^{15}$ A. Kalniņš, 'Izglìitibas vadības un reformu demokratizācija Latvijā’ [Democratisation of education leadership and reforms in Latvia], Latvijas Vēstnesis [Latvian Herald], 18 May 1995. Available: https://www.vestnesis.lv/ta/id/27208, (accessed 20 September 2017).

${ }^{16}$ G. Catlaks, 'Demokrātiskās pārmaiņas izglìtībā; valsts izglìtības politikas pārskats 1991-2001' [Democratic changes in education; state educational policy review 1991-2001], Providus, 20 November 2001. Available: http://providus.lv/article/demokratiskas-parmainas-izglitiba-valstsizglitibas-politikas-parskats-1991-2001 (accessed 13 October 2016).
} 
affected teachers and students at all levels of the education system. The reforms did not consider the existing Soviet culture of education that had been in place throughout occupation, and it often appeared that the political elite were also not invested in the programme. Much like the overall reforms for education, the initiative for history teachers were fragmented and few and far-between.

The 2000 OECD report, which analysed higher education policies for teacher education, expressed concern that there was no mechanism or policies in place guaranteeing investment in solutions to reaching goals of national priority. Although higher education institutes played the main role in teacher preparation and continuing education, the existing well-meaning initiatives were primarily 'pilot projects' initiated from external sources and did not have the support of the main university-level educators or the government. The many colleges that had sprung up needed qualified instructors, but the traditional methods for preparation of university level lecturers and general education teachers were not appropriate for this level of instructors. In other words, all levels of education, including tertiary education, needed to be included in education reform. ${ }^{17}$ This period was characterised by much public criticism of a system that had lost control of the education system and lost sight of the purpose of reforms. The OECD expert committee suggested that some of the decentralisation of education, which led to loss of control by the Ministry of Education over some education sectors, be abandoned, and a more equitable system be devised. The initial euphoria of democratic education practices had ended and calls for a return to familiar teaching practices became more vocal.

Finding a balance (1999-2004). The period from 1999 on focused on the positive realisation that adoption of new ideas could be combined with positive aspects from the existing culture of education. Lack of funding for many of the previously initiated reforms resulted in frustration, and many teachers called for returned focus on the student. There was a call for drawing on existing positive elements in the education system, and not just for initiatives from outside. ${ }^{18}$ As regards the Ministry of Education, the report noted that many gradual changes had taken place, but there had been minimal strategic reforms. ${ }^{19}$ The OECD viewed this as a critical point for Latvia, as it needed to create an education system based on a sense of ownership and belonging in order to achieve equity and harmony among the citizens of Latvia and the realities of life, the economy, and culture. ${ }^{20}$ This included not only democratic teaching practices, but also creation of curriculum to unite the country.

\footnotetext{
${ }^{17}$ Ekonomiskās sadarbības un attīstības organizācija (OECD), Valsts izglìtības politikas analīze Latvija [National Education Policy Analysis - Latvia], Ekonomiskās sadarbības un attīstības organizācija (OECD), 2000, p. 71. Available: http://viaa.gov.lv/files/news/521/oecdaug8.pdf (accessed 13 October 2016).

${ }^{18}$ Ibid., pp. 29, 75.

${ }^{19}$ Ibid., p. 20.

${ }^{20}$ Ibid., p. 75.
} 


\section{Challenges to teaching history}

In addition to reforms in teaching practices and education administration, one of the most pressing problems after the renewal of independence was the creation of a national education programme that supported and encouraged the 'Latvianisation' of all educational processes for the purpose of creating a society in which non-ethnic Latvians would be fully integrated and able to function in Latvia. Fifty years of intense Russification and Sovietisation had left its mark, and renewed Latvian independence presented challenges to the creation of an inclusive society, which identified with the Latvian state. One of the most pressing issues was the recreation of a history curriculum that presented the Latvian version of Latvian history.

Under Soviet rule, the goal of history teaching was to create a Soviet interpretation of Latvia's history as a means to instill Soviet patriotism, create a worldview based on a unified system grounded in one correct version of history, and legitimise and glorify the existing regime. During Soviet occupation, history as a subject was uniform, and teachers had virtually no access to materials created during the interwar period or foreign sources. Inspired teachers who taught general history strove to find materials and methods that would make lessons more interesting for the pupils, but teaching $20^{\text {th }}$ century history or Latvian history was often avoided because of its contentious content: existing teachers had been thoroughly indoctrinated in the Russo-centric version of history, which consistently denigrated the historic achievements of Latvia, particularly those of independent Latvia during the interwar period. This situation resulted in teachers, who were well trained in a unified Soviet historiography and formalist teaching approaches, having to suddenly adopt unfamiliar methodology as well as an unfamiliar curriculum.

Language issues also played a role. Many teachers were part of the Russianspeaking mass of migrants brought from other parts of the Soviet Union after World War II, most of whom had no knowledge of Latvian history and could not speak Latvian. However, being an ethnic Latvian was no guarantor of knowledge of a Latvian interpretation of history. Interviews with history teachers and students who taught and/or studied during Soviet occupation reveal that many parents and grandparents did not discuss life in independent Latvia or events they had witnessed during the war with their children and grandchildren as they feared that the child would inadvertently repeat this information at school, which could result in serious repercussions for the entire family. $^{21}$

Thus, history teachers in Latvian schools in the 1990s were charged with implementing an untested, unknown, and, for some, a highly contentious history curriculum. The most pressing issue after the renewal of independence was acceptable history textbooks, admittedly the most widely used resource in

\footnotetext{
${ }^{21}$ For an in-depth discussion of the memories of students and teachers of history in Sovietoccupied Latvia, see: A. Abens, 'The Effects of Authoritarianism on the Teaching of Latvian History', PhD diss., University of Latvia, 2011.
} 
history classes. Removal of old textbooks in the early 1990s resulted in teachers, once again, creating new teaching materials to replace the ones that were no longer politically acceptable. Even textbooks about ancient history were pulled from the shelves because the focus was on class struggle, no longer an acceptable basis for the interpretation of history. Long-hidden interwar period history books were unearthed, but these too no longer reflected the needs and views of modern democratic education principles. New, more modern history textbooks were quickly created based on a Latvian historiography.

In general, since 1991, history teachers in Latvia have adopted the accepted notion of history as being a multi-faceted subject by using a neutral, factual approach to historic periods in attempts to be non-judgmental and present various perspectives on contentious historic issues. History textbook authors followed the traditional method of presenting information chronologically, focusing on names, dates, and places. Simplified Latvian history textbooks were created for elementary school pupils, which were translated into Russian, indicating the need to present the Latvian interpretation of history to a large Russian-speaking minority.

Most notably, they have moved away from the blatant nationalism characteristic of the Soviet totalitarian regime. As a point of comparison in the discussion of the $12^{\text {th }}-13^{\text {th }}$ century Teutonic invasions, a modern Latvian history textbook for secondary schools ${ }^{22}$ is much more accurate in its description of locations and tribes using historic names, not modern national identifiers. The maps used to describe events of the time are localised, but they also include others maps that show Latvian territory within the framework of Europe to help students understand why the local map looks as it does. Language in the book is not sanitised to make Latvians look more positive in historic context, nor does it glorify historic successes. However, it is laden with text, illustrations, and tables, and although it offers differing views of historic events in Latvian history, it does not pose questions for thought or reflection, nor does it attempt to explain differences of interpretations of facts. Such descriptions might help to build student awareness of different interpretations of history and develop historical thinking. History teaching has often been touted as an exemplary forum for utilizing various teaching methods for developing critical thinking skills. These methods encourage moving away from old-fashioned history lesson with teacher-driven acquisition of 'acts and facts' ${ }^{23}$ towards a more democratic classroom in which student-centred activities encourage discussion of citizenship and multiple historic narratives. That this had not occurred in terms of history textbook writing is apparent in the 2000 OECD report comment that Latvian textbooks in general reflected adherence to

${ }^{22}$ G. Kurlovičs, A. Tomašūns, Latvijas vēsture vidusskolai, 1.sēj. [Latvian History for Secondary school, vol.1], Rīga, Zvaigzne ABC, 1999.

${ }^{23}$ M. Depaepe, 'Dealing with the Historic Paradoxes of a Globalised Educationalisation - A Way to Write the "New" Cultural History of Education?', in M. Cijntje-Van Enckevort, M. George (eds.), Re-thinking Education in the Caribbean: Yesterday, Today and Tomorrow - A Local Imperative in a Global Context, Philipsburg (N.A.), University of St. Martin, 2006, p. 37. 
antiquated teaching standards: in order to support teachers' efforts in applying new teaching methods, new books were needed. ${ }^{24}$

Some historians and academics addressed this problem by creating some methodological resources, which openly discussed the problems of various interpretations of historic facts and even offered lesson plans with guidelines for democratic approaches to teaching contentious issues.

Gundare introduced a handbook on history teaching in which she stressed that times have changed and there is no longer a 'correct' history, and that as long as Latvia is a democratic nation and society, differing views and opinions will be tolerated, if not respected..$^{25}$ This handbook was designed for teachers to review the most contentious aspects of Latvian history and to help overcome the divisions in modern Latvian society.

In this same handbook, Kiilis offered a social anthropological view of history as a point of reference for teachers, ${ }^{26}$ which differed greatly from the one in which they were educated during the Soviet era. The handbook presented concrete lesson plans and suggestions on how to teach what can be considered the most debated historic periods in Latvian history, including the incorporation of Latvian territories into the Russian empire during the reign of Peter I, the Ulmanis regime, activities of Latvian soldiers in the German and Soviet armies during World War II, the resistance and partisan activities following World War II, and the collectivisation of the Latvian countryside. The handbook, published by the Latvian History Teacher Association, was also translated into Russian indicating that Latvian history continued to be taught by Russian-speaking teachers to Russian-speaking pupils.

A collection of papers presented at conferences of Lithuanian and Latvian history teachers at Daugavpils University from 1998 to $2001^{27}$ gives several examples of history lessons and methods being used at the time. Of the five papers published in Latvian, all discussed methods of teaching but had no reflections on actual lessons. One lesson on patriotic up-bringing during history lessons in Grade 5 discussed the necessity of teaching history at a local level for instilling patriotism. This could be achieved through trips to locally significant places and revisited later outside of class on weekends or holidays in cooperation with the homeroom teacher and the prescribed advisory curriculum. Use of competitions to test student knowledge, enjoyed by all students regardless of

${ }^{24}$ Ekonomiskās sadarbības un attīstības organizācija (OECD), Valsts izglìtības politikas analizze Latvija [National Education Policy Analysis - Latvia], Ekonomiskās sadarbības un attīstības organizācija (OECD), 2000, p. 28. Available: http://viaa.gov.lv/files/news/521/oecdaug8.pdf (accessed 13 October 2016).

${ }^{25}$ I. Gundare (ed.), Pretruniga vēsture [Contradictory history], Rīga, Latvijas Vēstures skolotāju asociācija, 2000, p. 5.

${ }^{26}$ R. Ķilis, 'Vēstures pretrunīgums: interpretācijas, fakti, notikumi' [Historic contradictions: Interpretations, facts, events], in I. Gundare (ed.), Pretrunigga vēsture [Contradictory history], Rìga, Latvijas Vēstures skolotāju asociācija, 2000, pp. 8-12.

${ }^{27}$ I. Saleniece, I. Šēnberga (eds.), Vēstures mācību aktualitātes skolā - DU vēstures katedras II-IV metodiskās konferences rakstu kräjums [Developments in history teaching in schools - DU history department II-IV methodology conference papers], Daugavpils, Saule, 2001. 
level of knowledge, was also a suggested method. Students could also be placed in the role of tour guide who would explain facts to fellow students. ${ }^{28}$ However, the methods suggested are not much different than previously used Soviet methods and differ mainly in that the terms 'democratic nation' and 'European citizen' replaced 'socialism' or 'communism' and 'Soviet citizen'. They are replicative in nature, and do not offer students opportunities to critically assess, analyse, or offer deeper explanations for events. Suggestions on implementation were not given, and reflections on actual lessons or more modern methods of developing critical thinking skills were lacking. Perhaps this can be explained by the lack of experience Latvian history teachers had with the democratic teaching process in their teacher education, which was exacerbated by a lack of didactic texts and examples of good practice in the Latvian context. This also supports the 2000 OECD assessment that teachers do not understand how to differentiate between skills and knowledge, indicating that more intensive teacher training is needed. ${ }^{29}$

The use of local history, as mentioned above, to introduce historical thinking and develop a sense of national identity among younger students is a common feature in history curricula in democracies. Yet in Latvia, this has not had the desired effect, as noted in the 2004/2005 joint United Nations Development Programme and Advanced Social and Political Research Institute (ASPRI) of the University of Latvia report. ${ }^{30}$ The report analysed surveys and interviews with educators throughout Latvia. It noted that national identity and a sense of belonging that turns separate individuals into a civic and responsible society are high in Latvia, yet conflicting, ${ }^{31}$ with the greatest differences in the sense of belonging based on ethnic affiliation..$^{32}$ On a national level, the vast majority of citizens (92\%) felt an affiliation with Latvia, ${ }^{33}$ but as regards regional identity, non-ethnic Latvians (i.e. Russian-speakers) tended to look east to Russia while ethnic Latvians identified with Europe. ${ }^{34}$ These identifiers clearly have roots in history, as most Russian-speakers were relatively recent migrants or their descendants from Soviet republics (most notably Russia, Ukraine, and Belarus), but Latvia's cultural history is firmly tied to Europe. While Russian-speakers have

\footnotetext{
${ }^{28}$ L. Brokāne, 'Patriotiska audzināšana' [Patriotic upbringing], Vēstures mācību aktualitātes skolā - DU vēstures katedras II-IV metodiskās konferences rakstu kräjums [Developments in history teaching in schools - DU history department II-IV methodology conference papers], Daugavpils, Saule, 2001, pp. 40-43.

${ }^{29}$ Ekonomiskās sadarbības un attīstības organizācija (OECD), Valsts izglìtības politikas analīze Latvija [National Education Policy Analysis - Latvia], Ekonomiskās sadarbības un attīstības organizācija (OECD), 2000, pp. 28-29. Available: http://viaa.gov.lv/files/news/521/oecdaug8.pdf (accessed 13 October 2016).

${ }^{30}$ A. Zobena (ed.), Latvian Human Development Report, Riga, UNDP Latvija, 2005, p. xx. Available: http://www.szf.lu.lv/fileadmin/user_upload/szf_faili/Petnieciba/sppi/tautas/Demokratijas_ atskaite_9.pdf (accessed 13 October 2016).

${ }^{31}$ Ibid., p. 44.

${ }^{32}$ Ibid., p. 28.

${ }^{33}$ Ibid., p. 109.

${ }^{34}$ Ibid., p. 28.
} 
been integrated into economic processes, they have not discovered common values in the cultural space, as demonstrated by the considerable number of that segment of the population that does not speak Latvian and has little knowledge of Latvian history and Latvian cultural values, cultural peculiarities, and cultural codes. At the time of writing, the report's authors noted that a comparatively narrow circle of specialists were aware of the importance of cultural historical legacy - local, national, and regional - for the development of identity ${ }^{35}$ In addition, the suggested list of tasks and recommendations to help develop a sense of identity did not include school or history teaching as a way to promote positive identity affiliations. ${ }^{36}$

Thus, it is no surprise that a debate ensued about whether to teach Latvian history as a separate subject or incorporate it into the general course of world history. After regaining independence, Latvian history was included within the framework of European and world history. During Soviet occupation, USSR history, and later the history of the Latvian SSR, had been taught as a separate subject apart from general world history. In 1999, the Humanities and Social Sciences department at the Academy of Sciences called for the introduction of the teaching of Latvian history as a separate subject in Latvian schools. ${ }^{37}$ The difficulties of introducing this proposal were highlighted by discussion of the costs incurred in the creation of methodological materials necessary for a separate Latvian history course. These difficulties were attributed to teachers who were not qualified to teach history or who were not trained historians. It was also noted that this could particularly affect Russian and other minority language schools in which students may have had experience with alternative interpretations of particularly contentious events in Latvian history. However, as noted, a sufficient number of Latvian history books were already available to teachers and the quality of the lessons would depend highly on the interest of the teachers in the subject matter and an "honest" approach by the teacher to interpretations of documents and facts available. Teachers who were able to utilise creative teaching methods would also have no problem teaching this additional subject. Yet, the debate did not focus on teaching methods, but rather on acquisition of additional facts, resulting in an added burden on teachers, as well as students, due to insufficient time to acquire an already dense curriculum.

A separate course for Latvian history took over ten years to develop and was only implemented in the 2011/2012 school year. Although much of the debate focused on financial and methodological issues, this lengthy preparation period clearly indicates the highly politicised and conflicting views on teaching Latvian history, resulting from the not-so-distant Soviet occupation during which Latvian history teaching had been highly politicised in the public sphere and

\footnotetext{
${ }^{35}$ A. Zobena (ed.), Latvian Human Development Report, Riga, UNDP Latvija, 2005, pp. 44-45.

${ }^{36}$ Ibid., pp. 109-112.

${ }^{37}$ A. Cālìte, 'Latvijas vēsture sakṇojas katrā dzimtā' [Latvian history originates in every family], $L V$ Portāls, 28 June 2011. Available: http://m.lvportals.lv/visi/likumi-prakse?id=232196 (accessed 13 October 2016).
} 
which often conflicted with the version of history discussed in private. ${ }^{38}$ Yet, the additional material needed to be covered for testing purposes, resulting in continued focus on fact acquisition.

Continued adherence to teacher-centred methodology is often self-inflicted by teachers trying to reach state-mandated curriculum standards to guarantee student performance in comprehensive tests. ${ }^{39}$ This body of knowledge is almost always too vast, and testing requires students to acquire information to prove their knowledge. Students then quickly forget it in preparation for the next test, resulting in superficial understanding and a sense that knowledge is created by authorities from above, neglecting the students as stakeholders in the educational process. In fact, the majority of Latvian educators and teachers across the board admitted that teaching in Latvia was firmly grounded in the acquisition of facts and not in the development of critical thinking skills and application of knowledge to real life situations. ${ }^{40}$ In tune with the growing trend for a return to a more controlled system, a standardised centralised exam in history was piloted in 1996/1997.

A 2002 report on the introduction of centralised exams ${ }^{41}$ analysed the process and policies. The report concluded that the secondary school system, as it had been developed during Soviet occupation, remained intact, but that entry to higher education had lost its elite status and was now available to the masses. To facilitate this process, centralised exams would eliminate the need for separate secondary school finals and higher education entrance exams by combining them into one, which reflected practice generally accepted in Europe. Yet, the report also noted that this centralised exam encouraged studying for the test, with no opportunity for feedback; however, the main function was not to assess individual performance, but rather determine how well a school was teaching its students, ${ }^{42}$ a commonly noted purpose for centralised examinations.

The centralised exam in history was created in three parts: the first tested factual knowledge (worth $40 \%$ of the total mark); the second tested ability to work with primary sources (also worth $40 \%$ ); and the final section required the students to analyse material (worth 20\%). The second and third exam sections were created to see how well a student could analyse the material presented. Analysis of results showed that students did not do very well overall, with weak results in the second section and even poorer results in the third.

${ }^{38}$ For an in-depth discussion on the 'folklorisation' of Latvian history, see: A. Abens, 'The Effects of Authoritarianism on the Teaching of Latvian History', PhD diss., University of Latvia, 2011.

${ }^{39}$ L. Cuban, 'Hugging the Middle Teaching in an Era of Testing and Accountability, 19802005, Education Policy Analysis Archives, vol. 15, 2007, pp. 1-27.

${ }^{40}$ Ekonomiskās sadarbības un attīstības organizācija (OECD), Valsts izglìtības politikas analìze Latvija [National Education Policy Analysis - Latvia], Ekonomiskās sadarbības un attīstības organizācija (OECD), 2000, p. 28. Available: http://viaa.gov.lv/files/news/521/oecdaug8.pdf (accessed 13 October 2016).

${ }^{41}$ Centralizēto eksāmenu ieviešana [Introduction of centralised examinations], Rìga, Baltijas Sociālo zinātṇu institūts, 2002. Available: http://www.biss.soc.lv/downloads/resources/centrEks/ centrEks.pdf (accessed 13 October 2016).

${ }^{42}$ Ibid., p. 5. 
It was noted, that the low weight given to the most difficult part of the test analysis - encouraged some students to ignore this section altogether or write something nonsensical. While deficiencies in the centralised exam system were identified and improvements suggested, most notably by increasing the value of the analysis part of the test, the report noted that it was still a more equitable system for university entrance. ${ }^{43}$ The acknowledged benefits of centralised exams notwithstanding, the report clearly indicated that history teaching and learning had yet to adopt more democratic teaching principles.

Democratic teaching principles can only be achieved through development of critical thinking skills, a subject that was briefly touched upon, but true reflection on this as practice appeared to be lacking in discussion on democratic education practice in general and the teaching of history specifically in Latvia. Rubene ${ }^{44}$ noted that educational institutions as social structures have traditionally been conservative, but the nature of the Soviet school system, where schools were specifically subjected to totalitarian ideological norms and standards, has resulted in the continuation of a closed social model, even after political transformations have taken place. She continued that educational institutions are not only catalysts for social change through reforms in the system but through particular emphasis on participation in emancipatory and self-determination processes. ${ }^{45}$ This appeared to be lacking, as demonstrated by comments made by a parent whose children attended school in the early 2000s and who testified to a lack of this process in history lessons. She noted the similarity between the Soviet era and the current era:

It upsets me more that supposedly correct history teaching today is entrusted to 'strange' teachers - my youngest son can't stand history. I went to [his] school - the history teacher there is a formalist, pedantic, and completely stiff. History has to be recited like a verse, and when opinions are requested, they have to concur with the teacher's. This was clear 30 years ago when that was required by a foreign power, but now? I have no supporting arguments to say that this type of history teaching is important. ${ }^{46}$

This reflection on the state of the teaching of history indicates that the shift from the authoritarian style of teaching to one characteristic of democracies is not a simple process. This discussion of the post-Soviet era of history teaching indicates a progression and growth of Latvian awareness in history teaching that conflicts with the internalised motivation and purpose as experienced during the Soviet regime. The current ruling order professes to view history from

${ }^{43}$ Ibid., pp. 61-63.

${ }^{44}$ Z. Rubene, 'Jauniešu kritiskās domāšanas izpēte studiju procesā universitātē' [Research on critical thinking in youth in the study process in university], $\mathrm{PhD}$ diss., University of Latvia, 2003, p. 244.

${ }^{45}$ Ibid., p. 156.

${ }^{46}$ A. Abens, 'The Effects of Authoritarianism on the Teaching of Latvian History,' PhD diss., University of Latvia, 2011, p. 171. 
a democratic perspective in which a unified history creating a unified identity is no longer considered to be positive trait. The purpose of history teaching continues to emphasise gaining knowledge, although modern democratic principles would encourage a stress on critical-thinking.

History taught in schools is required to obey political demands and must respond to the pressures of the socio-cultural context in which it is taught. In some contemporary societies, it is demanded that the memories of particular groups or communities, sometimes considered the 'Other' are taken account of in the history curriculum. UNESCO suggests that by providing reliable texts and sources that help students to see the perspective of the 'Other', we can hope to move students from an adherence to a mythologised past to a meaningful historical understanding. ${ }^{47}$ This can be achieved by creating enquiry questions to engage students, rather than recitation of facts and figures, in which there are sometimes omissions and distortions and that offer a superficial view. UNESCO's document notes that such distortions and omissions do not always represent a conscious attempt to present a narrow and one-sided view of history on the part of textbook authors; rather, they are the product of the wider political and cultural context in which history textbooks are written. ${ }^{48}$ The overt Russo-centric nationalism apparent in Soviet history textbooks may have resulted in an internalised aversion to creation of Latvian history books that 'glorify' Latvian history, as well as the teaching of Latvian history that does the same. Yet, the presence of a significant number of inhabitants who do not have a lengthy historical connection to Latvia may require such an approach so that they understand local cultural codes and values and become more integrated into Latvian society.

Many history teachers in Latvia have also declared that teaching Latvian history separately results in confusion among students about the interconnectedness of events in Latvia, Europe, and the world as a whole. The Latvian History Teacher Society has also publicly come out against teaching Latvian history as a separate subject, supporting the overall principles of EUROCLIO (European Association of History Educators), of which it is a member, that encourages supranational history education to support and strengthen democratic principles. The stress on supranational history may be a backlash against war on European soil, notably World War II and other conflicts, in which specific ethnic and religious groups have been objectified and targeted. Some Latvian historians still associated national history teaching with hero glorification and stress on accomplishments and struggle, possibly indicating negative associations with the way history was once taught. Historian Juris Celmiņš questioned whether the actual issue was history content or

\footnotetext{
${ }^{47}$ Islamic Educational, Scientific and Cultural Organisation, et al., Guidebook for History Textbook Authors, UNESCO, 2012, p. 15. Available: https://unesdoc.unesco.org/ark:/48223/pf0000227041? posInSet=1\&queryId=0377d35d-3ce5-4508-8ce8-9766da557428 (accessed 13 October 2016).

${ }^{48}$ Ibid., p. 19.
} 
rather teacher inability to use appropriate, modern teaching practices, ${ }^{49}$ clearly indicating that by 2004, society, historians, and teachers had yet to overcome certain stereotypes, including those associated with national history teaching and patriotism. The glorified patriotism endemic in the Soviet system may have been and may continue to be a bad memory, resulting in a practice of avoidance of national history teaching.

The discussion of the realities of history teaching in renewed independence reveal problems of an ageing teaching staff, educated under the Soviet system, who have not embraced democratic teaching practices, indicating that many formalist practices have become internalised. Younger teachers, educated after 1991, continued to propagate these teaching practices indicating that a shift towards a more open and creative methodology does not occur naturally and must be not only be taught, but also practiced.

\section{Conclusion}

There is an old adage in the field of education - we teach as we were taught. If this is true, it is no wonder that democratic teaching practices are yet to be accepted and used widely in Latvia. This discussion of democratic teaching practice in post-Soviet Latvia indicates that progress and growth of Latvian awareness of democratic teaching processes conflicts with internalised motivation and purpose and has, indeed, resulted only in a restructuring of the education system, as noted in 1995 by MoES secretary Kalniňš, including the weakening of the role of the Ministry overall. The purpose of history teaching and education in general continues to stress knowledge acquisition, rather than critical thinking processes. Research in curriculum continues to be the domain of professional historians, although research on methods and materials is often taken on by teachers pursuing higher education. History books generally reflect the study of Latvian history through a European-centric lens. The discussion of the realities of teaching indicates that a shift away from internalised methodology towards more open and creative practices does not occur naturally.

History teaching in the post-Soviet period of Latvian independence reflects various views of history that include internalised Soviet axioms, historic interpretations adopted from the interwar period, and modern views. Research in general education practices, as well as the content of history textbooks, are quite liberal and focus on the most modern educational perspectives. Access to funding for teacher training has increased. But, adopting democratic teaching practices, as we understand them today, has proven to be a difficult challenge for those societies that have experienced a sudden break in political systems, transferring from authoritarianism to democracy. This sudden break

\footnotetext{
${ }^{49}$ J. Celmiñš, 'Latvijas vēstures mācīšana stereotipu gūstā' [Latvian history teaching as a captive of stereotypes], Providus, 29 November 2005. Available: http://providus.lv/article/latvijas-vesturesmacisana-stereotipu-gusta (accessed 24 February 2017).
} 
is also a challenge for teachers, who must now teach a history curriculum that contradicts the Soviet historiography they had once accepted and may still accept to be fact. It is clear that simply adopting the practices used in countries with lengthy democratic experience does not consider the baggage that newly democratic societies bring with them. Sometimes the pendulum swings wildly from one side to the other, and finding a practical balance that addresses all issues is certainly not without its pitfalls.

Latvia joined the EU in 2004 and in rhetoric, at least, has adopted the democratic values supported by the EU. However, recent political events in Europe have caused these values to come into question. The concepts of integration and tolerance upon which European society are based have recently come under attack and are often considered to be indications of loose morality and the 'cosmopolitan' nature of Western European society. Even in what are considered established Western European democracies, the discussion about history curriculum revolves around nationalism in the face of multiculturalism, which appears to threaten a sense of national identity. ${ }^{50}$ Shifts in these views have also occurred in Latvia on a national level with the introduction of legislation that supposes to define moral and patriotic values. ${ }^{51}$

The question remains whether methods adopted through a teacher's lived experience are changeable through education alone. Perhaps more radical changes in the teacher preparation system and an entire generational change need to take place before the education system can be considered reflective of the democratic ideals proposed by the various bodies involved in the teaching and learning process.

50 'Notes on a Small Island', The Economist, 20 August 2005, p. 24; D. Bilefsky, 'Modern Belgians Return to 'Glorious' Middles Ages', International Herald Tribune, 4 April 2007, pp. 1-8.

${ }^{51}$ G. Valdmanis, 'Pēc garām diskusijām Saeima tomēr apstiprina skolotāju "lojalitātes grozijumus"” [After lengthy discussion, Parliament adopts teacher 'loyalty changes'], Latvijas Sabiedriskie Mediji [Public broadcasting of Latvia], 23 November 2016. Available: http://www.lsm.lv/lv/ raksts/latvija/zinas/pec-garam-diskusijam-saeima-tomer-apstiprina-skolotaju-lojalitatesgrozijumus.a211388/ (accessed 20 September 2017). 